Systemy Logistyczne Wojsk

Zeszyt 54 (2021)

ISSN 1508-5430, s. 105-123

Military Logistics Systems

Volume 54 (2021)

ISSN 1508-5430, pp. 105-123
Instytut Logistyki

Wydział Bezpieczeństwa, Logistyki i Zarządzania

Wojskowa Akademia Techniczna

w Warszawie

Institute of Logistics

Faculty of Security, Logistics and Management Military University of Technology

in Warsaw

\title{
Legal Instruments of the State Sanitary Inspection - Amendments to the Act on the State Sanitary Inspection in the Face of the Pandemic
}

\author{
instrumenty prawne państwowej inspekcji sanitarnej \\ - zmiany ustawy o państwowej inspekcji sanitarnej \\ w obliczu pandemii
}

\author{
Konrad Kacała \\ konrad.kacala@onet.eu; ORCID: 0000-0002-4466-3389 \\ Główny Inspektorat Sanitarny, Polska \\ Chief Sanitary Inspectorate, Poland
}

\begin{abstract}
The emergence of the new coronavirus SARS-Co2-V and the infectious disease (COVID-19) which it causes required immediate state-level decision-making in a number of areas including, for example, politics, health, economy, system of preschool and school education, research, border crossing, mobility, etc. The research problem presented in the article is assessment of whether the statutory changes did actually address the situation and the issue of ensuring safety, including sanitary and epidemiological safety, from COVID-19 infectious disease and the SARS-CoV-2 virus causing the disease, what the changes were and what their character is. The hypothesis presented in the article is that the direction of the implemented statutory changes, manifested in the introduction of new legal measures of various nature, is relevant to the situation and to ensuring safety. It became necessary to create the possibility of using new instruments in specific cases related to infections or infectious diseases, increasing the speed of issuing and executing decisions imposing obligations specified by the Act on the State Sanitary Inspection, creating the possibility of supplementing the applicable regulations by issuing recommendations and guidelines for individual addressees, which gives possibility of detailed definition of norms of conduct. The purpose of this article is to discuss key regulatory developments. The focus is on the State Sanitary Inspection (SSI). The deliberations are focused on the history of sanitary-epidemiological services in Poland, the issue of sanitary-epidemiological safety and, most importantly, the new legal instruments introduced to the Act on the State Sanitary Inspection, regulating its activities in the field of risk prevention. The basic research method used in the article is the legal-dogmatic method. The article closes with a summary, conclusions, final verification of the hypothesis and indications for further research.
\end{abstract}


Keywords: sanitary-epidemiological safety, COVID-19, state of epidemic, legal regulations, State Sanitary Inspection

Abstrakt. Pojawienie się nowego koronawirusa SARS-Co2-V i wywoływanej przez niego choroby zakaźnej COVID-19 wymagało - na szczeblu państwa - podejmowania natychmiastowych decyzji w wielu obszarach, w tym na przykład w odniesieniu do polityki, funkcjonowania służby zdrowia, gospodarki, systemu edukacji przedszkolnej i szkolnej, badań naukowych, przekraczania granic, mobilności itp. Problemem badawczym postawionym w artykule jest ocena czy ustawowe zmiany miały faktycznie na uwadze powstałą sytuację i zapewnienie bezpieczeństwa, w tym sanitarno-epidemiologicznego przed chorobą zakaźną COVID-19 i wywołującym ją koronawirusem SARS-CoV-2, w czym się dokładnie przejawiły, jaki mają charakter. Hipotezą artykułu jest twierdzenie, że kierunek dokonanych zmian legislacyjnych, przejawiający się we wprowadzeniu nowych środków prawnych o różnym charakterze uwzględnia powstałą sytuację i zapewnienie bezpieczeństwa. Konieczne stało się stworzenie możliwości stosowania nowych instrumentów w określonych przypadkach związanych z zakażeniami czy chorobami zakaźnymi, zwiększenie szybkości w wydawaniu i wykonaniu decyzji nakładających określone ustawą o Inspekcji Sanitarnej obowiązki, stworzenie możliwości uzupełniania obowiązujących regulacji poprzez wydawanie zaleceń i wytycznych w stosunku do poszczególnych adresatów i wytyczanie w ten sposób norm postępowania. Celem niniejszego artykułu jest omówienie najważniejszych zmian w zakresie regulacji prawnych, które zaszły w ostatnim okresie związanym z pojawieniem się koronawirusa, COVID-19. Skupiono się na Państwowej Inspekcji Sanitarnej (Inspekcja Sanitarna). Omówiono historię służb sanitarno-epidemiologicznych w Polsce, scharakteryzowano zagadnienie bezpieczeństwa sanitarno-epidemiologicznego na podstawie obowiązujących przepisów prawnych, a przede wszystkim scharakteryzowano wprowadzone do ustawy o Państwowej Inspekcji Sanitarnej nowe instrumenty prawne regulujące jej działania w zakresie przeciwdziałania zagrożeniu. Podstawową metodą badawczą zastosowaną w artykule jest metoda prawno-dogmatyczną. Artykuł wieńczą podsumowanie, wnioski, końcowa weryfikacja hipotezy i wskazanie kierunków dalszych badań. Słowa kluczowe: bezpieczeństwo sanitarno-epidemiologiczne, COVID-19, stan epidemii, regulacje prawne, Państwowa Inspekcja Sanitarna

\section{Introduction}

It has been more than a year since the first case of SARS-CoV-2 coronavirus infection in Poland was revealed to the public (the official website of the Polish government - Serwis Rzeczypospolitej Polskiej, https://www.gov.pl/web/zdrowie/ pierwszy-przypadek-koronawirusa-w-polsce). Between that date (3/4 March 2020) and May 2021, more than 2,500,000 infected and more than 65,000 deaths were recorded in Poland. The consequence of the outbreak of the coronavirus in Poland was primarily the introduction of a state of epidemic emergency on the territory of the Republic of Poland (Regulation of the Minister of Health of 13 March 2020 on the declaration of a state of epidemic emergency on the territory of the Republic of Poland (Journal Laws of 2020, item 433, as amended), Chapter $1, \$ 1$ ), and then a state of epidemic (Regulation of the Minister of Health of 20 March 2020 on the declaration of a state of epidemic emergency on the territory of the Republic of Poland (Journal of Laws of 2020, item 491, as amended), Chapter $1, \$ 1$ ). The above has undoubtedly caused changes in numerous areas of the functioning of the state, its citizens, affecting in particular the activities of both public institutions and private entities, as well as social relations (Borucka, Łagowska, 2020, p. 38). The danger of COVID-19 infections, a hitherto unknown coronavirus SARS-CoV-2, resulted not 
only in the introduction of a state of epidemic itself, but also in other actions taken by the state in the form of preparation and subsequent implementation of changes in legal regulations, which were intended to ensure broadly understood safety.

The research problem presented in the article is assessment of whether the statutory changes did actually address the situation and the issue of ensuring safety, including sanitary and epidemiological safety, from COVID-19 infectious disease and the SARS-CoV-2 virus causing the disease, what the changes were and what their character is. Taking into account the state of the epidemic, what makes the problem genuine and current is the novelty of introduced statutory changes, lack of case-law so far and lack of comprehensive doctrine statements.

The hypothesis presented in the article is that the direction of the implemented statutory changes, manifested in the introduction of new legal measures of various nature, is relevant to the situation and to ensuring safety.

This article aims to discuss the most important regulatory changes that have occurred in the recent period related to the outbreak of the coronavirus, focusing on the equipping of the State Sanitary Inspection (SSI) with new legal instruments that have been introduced in the Act of 14 March 1985 on the State Sanitary Inspection (Act of 14 March 1985 on the State Sanitary Inspection (Journal of Laws of 2021, item 195), Sanitary Inspection Act) and defining their specifics. Given the limited form of the article, the most important aspects of the issue were selected.

In order to introduce the analyzed subject, the article will feature an overview of more than 100 years of history of sanitary and epidemiological services in Poland, taking into account the most important events that concern it. Further into the article, the issue of safety will be discussed, with particular emphasis on sanitary-epidemiological safety, and finally, new legal instruments introduced to the Act on the State Sanitary Inspection will be discussed, as they are a response to the danger caused by the SARS-CoV-2 and COVID-19.

The article closes with a summary, conclusions, final verification of the hypothesis and indications for further research. The basic research method used in the article is the legal-dogmatic method, consisting of the analysis of legal acts, the study of legal literature, as well as case law, and the historical method, presenting changes in legislation.

\section{Historical overview}

The year 2019 marked the 100th anniversary of sanitary services in Poland. Less than a year after Poland regained its independence, the Principal Sanitary Act was issued, based on which the Ministry of Public Health was established, which is the fundamental document regulating the health care system in Poland, considered to be the beginning of sanitary services in Poland (Posobkiewicz, Kalinowska-Morka, 
Świekatowski, 2015, p. 114). It was a decree issued by the Head of State Józef Piłsudski, which came into force on 8 February 1919 (Principal Sanitary Act of February 1919 (Journal of Laws of 1919, No. 15, item 207)). Then, the Legislative Assembly passed the Principal Sanitary Law (Principal Sanitary Law of July 19, 1919. (Journal of Laws of 1919, No. 63, item 371)). Art. 1 of said Act stipulated that the Ministry of Public Health is responsible for the supervision of all health matters in the country and for the management of medical affairs, and among its competences, combating diseases in general, infectious diseases in particular, both acute and chronic (disinfection, disinsection, public baths, serum and vaccine manufacturing plants), is the first issue mentioned in Art. 2. In the initial stages of the rebirth of the Polish State, the Act of 25 July 1919 on combating infectious diseases and other common diseases was passed (the Act of 25 July 1919 on combating infectious diseases and other common diseases (Journal of Laws of 1919 No. 67, item 402)). Art. 3 of said Act listed diseases reportable to the sanitary authorities, of which acute infectious diseases constituted the largest number.

Undoubtedly, the above resulted from the situation of the country after World War I. Poor sanitary conditions contributed to outbreaks of infectious diseases. It was necessary to change the organization of state structures, in order to ensure the safety and health of the population in this overly important sector of anti-epidemic surveillance (Seweryn, 2015, p. 158).

The following period, prior to the outbreak of World War II, saw further development of sanitary-epidemiological structures. It is worth noting the establishment of the following on 7 September 1923 National Institute of Hygiene (PZH) on the foundation of the National Central Epidemiological Institute (PCZE) (Cianciara 2011, p. 637). The National Institute of Hygiene, since 2007 functioning as the National Institute of Public Health - National Institute of Hygiene (NIZP-PZH) continues to exist as an institution.

World War II ended the development of the sanitary-epidemiological surveillance system. At its end, on 24 November 1944, when Poland was in the state of extensive damage due to the War with numerous outbreaks of epidemic typhus, typhoid fever, and other epidemic diseases, the Chief Extraordinary Epidemic Commissariat was established in Lublin on the initiative of the Minister of National Defense and the Supreme Commander of the Armed Forces, which was joined by the National Institute of Hygiene later on (Klingberg in: Morzycki, Klingberg, 1946, pp. 11-45). By way of the Decree of 11 April 1945 on the division of the Ministry of Labor, Welfare and Health, established by the Act of 31 December 1944 (Decree of 11 April 1945 on the division of the Ministry of Labor, Welfare and Health, established by the Act of 31 December 1944 (Journal of Laws of 1945, No. 12, item 63), the Ministry of Health was established, to which the Chief Extraordinary Epidemic Commissariat was incorporated as a separate organizational unit by a circular of the Minister of Health of 25 June 1945 (Morzycki,1947, p. 8). 
When discussing the post-war history of sanitary-epidemiological services, it is impossible not to mention two acts. The first is the Resolution of the Presidium of the Council of Ministers No. 27/52 of 2 February 1952 on the establishment of sanitary-epidemiological and quarantine stations, on the basis of which provincial and district sanitary-epidemiological stations were established, which were to be responsible for ongoing supervision and sanitary-order actions, which took place by merging branches of the National Institute of Hygiene and provincial health departments (Główny Inspektorat Sanitarny (trans. Chief Sanitary Inspectorate), p. 15). The second is the Decree of 14 August 1954 on the State Sanitary Inspection (Decree of 14 August 1954 on the State Sanitary Inspection (Journal of Laws of 1954, No. 37, item. 160)), under which the State Sanitary Inspection was established, headed by the Chief Sanitary Inspector. The institution of State Sanitary Inspectors was established as organs of the State Sanitary Inspection, which as such was subordinate to the Minister of Health.

The enactment of the Sanitary Inspection Act on 1 September 1985 was a milestone for the Sanitary Inspectorate. To this day, the Act still forms the legal basis for regulating sanitary-epidemiological services. It has undergone a number of changes, including changes in its structure, i.e., in the vertical subordination of authorities, introduced alternately with the merger of inspection authorities with government administration (Act of 24 July 1998 on the amendment of certain acts determining the competencies of public administration authorities - in connection with the reform of the state system (Journal of Laws of 1998, No. 106, item 668, as amended); Act of 24 August 2001, amending the Sanitary Inspection Act and certain acts (Journal of Laws of 2001, No. 128, item 1407, as amended) Act of 23 January 2009 amending certain acts in connection with changes in the organization and division of public administration tasks within a voivodeship (Journal of Laws of 2009, No. 92, item 753, as amended)), establishment of the Chief Sanitary Inspectorate as of 1 January 2000 (Act of 24 July 1999 amending the Act on departments of state administration and certain other acts (Journal of Laws of 1999 No. 70, item 778), or the liquidation of State Sanitary Inspection of the Ministry of Interior and Administration on 1 July 2020 (Act of 23 January 2020 amending the Act on the State Sanitary Inspection and certain other acts (Journal of Laws of 2020, item 322)). The changes also involved increasing the tasks and scope of activity of the State Sanitary Inspection. As of 2002, as a result of the aforementioned Act of 24 August 2001, the State Sanitary Inspection has therefore been established not only to perform supervisory activities, as indicated by the provision of Art. 1 of the Act as at the date of its entry into force in 1985, but also to perform public health tasks, in particular by exercising supervision over the conditions listed in Art. 1 of the Act. Art. 3 of the Sanitary Inspection Act, which defines what falls within the scope of activity of the State Sanitary Inspection in the field of preventive sanitary supervision, was also amended by the above-mentioned Act by adding the phrase 
"in particular". At the same time, it is indicated that the list is exemplary in nature in the situation of the use of the phrase "in particular" in the Act, which in practice means that separate regulations may additionally impose other tasks falling within the scope of such supervision on SSI bodies (Kaczocha, 2017). Art. 6a was added, requiring the State Sanitary Inspection to issue an opinion as to the compliance with sanitary conditions defined by the European Union regulations of undertakings and completed investments, the implementation of which is supported by the Agency for Restructuring and Modernization of Agriculture with EU funds (Act of 16 February 2001 amending the Sanitary Inspection Act, the Act on the establishment of the Agricultural Market Agency, the Act on the establishment of the Agency for Restructuring and Modernization of Agriculture, the Act - Customs Code, the Act on control of infectious animal diseases, examination of animals for meat and the Veterinary Inspection, and the Act on the administration of foreign trade in goods and services (Journal of Laws of 2001 No. 29, item 320). However, most of the provisions of the Sanitary Inspection Act have not changed significantly. Until now, there have been legal instruments based, e.g., on Art. 5 sec. 1 item 4 of the Act, in the form of ordinances and decisions, or requests sent to other bodies for their issuance, in cases specified in the regulations on combating infectious diseases, or in Art. $27 \mathrm{sec} .1$ and 2. In light of the latter, a State Sanitary Inspector orders, in the event of finding a violation of sanitary and health requirements, by way of a decision, to remove the found deficiencies within a fixed period of time, whereby if the violation of the requirements referred to above caused an immediate threat to human life or health, the State Sanitary Inspector orders the closure of the workplace or its part (workstation, machine or other equipment), the closure of a public facility, the shutdown of a vehicle, the withdrawal from the market of a foodstuff, object of use or other product that may affect human health, or taking or ceasing other actions. Decisions in these cases are immediately enforceable.

Fig. 1 presents the current organizational structure of the State Sanitary Inspection. 

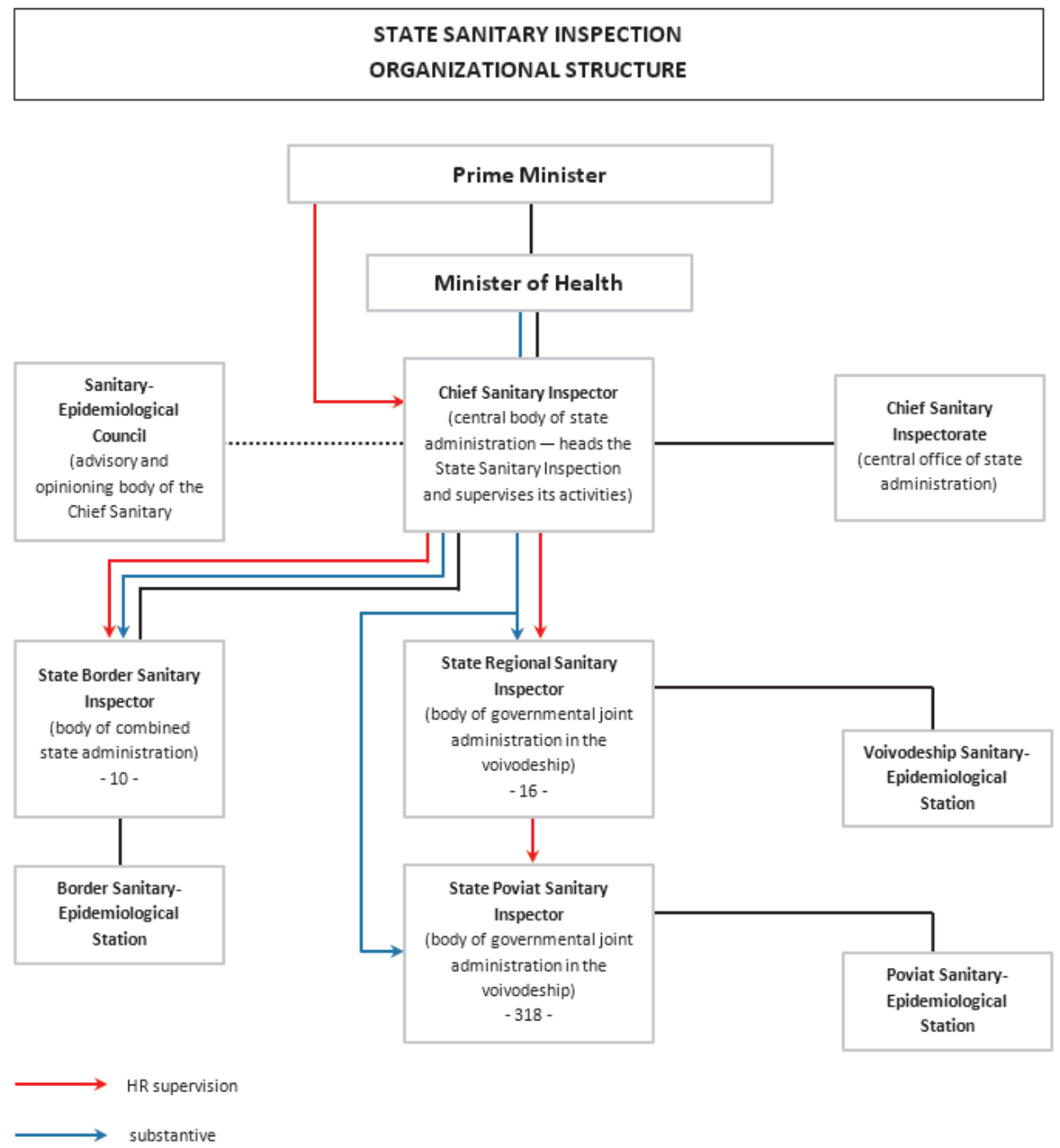

Fig. 1. State Sanitary Inspection, Organizational Structure Source: Own elaboration 


\section{Amendments to the Sanitary Inspection Act regarding the inspection instruments to ensure sanitary-epidemiological safety}

\section{Sanitary-epidemiological safety}

Safety is an unquestionable need and interest of every human being, in every area and situation (Janik, 2012, p. 57). Safety is also divided into a number of categories, including public safety. It is worth pointing out that public safety has no statutory definition and there are numerous explanations of its meaning. As a result of the review of views of the doctrine representatives, $M$. Janik proposed a definition that public safety is a positive state of affairs prevailing in a social organization, the preservation of which guarantees the avoidance of certain damage both by the whole organization and by its individual members. Such an understanding of the concept of "public safety" prioritizes the threat of unlawful attacks, violating certain goods (such as life, health, property), or more precisely the absence thereof. The above is justified on the grounds of case law, i.e., as a state in which "the general public, not individually identified, as well as other entities, including the state and public institutions, is not threatened by any danger and is not threatened by the disruption of the normal course of social life and the functioning of public institutions and facilities" (Janik, 2012, pp. 59-60).

In summary, safety exists when no threat of danger to a particular good (in the case of public safety, the absence of a threat of danger to the public is of significance, where human life is one of key goods).

In other divisions the following can be distinguished: health safety, patient safety, energy safety. However, focusing on anti-epidemic and sanitary issues, it is necessary to distinguish the part of common safety, aimed at protecting the population from biological hazards and poor sanitary conditions. Therefore, sanitary-epidemiological safety can be analyzed (Czechowicz, 2020a, p. 71). It is worth noting here that "sanitary-epidemiological safety is a socially desirable state that guarantees protection of public life and health from threats resulting from the sanitary condition, disease outbreaks dependent or not on human activity and other activities directed at loss of this safety and caused by man" (Czechowicz, 2020b, p. 17).

Considering the explanation in the context of public safety, it can be seen as including sanitary-epidemiological safety. Moreover, public safety also refers to the internal security of the state, with which it is also identified (Czechowicz, 2020b, p. 12). Viewing the category of safety as the internal security of the state, it can be said that sanitary-epidemiological security is its element (Czechowicz, 2020b, p. 17).

The concept of safety can also be referred to the regulations that are designed to ensure it. Such provision of safety, as a human right, is the responsibility of the state, or more precisely of specialized bodies at various administration levels. This 
means using appropriate legal (legislative in particular) measures of a functional and organizational nature. This process is not a one-time action and encompasses the above issues (Czechowicz, 2020a, p. 71).

The primary piece of legislation addressing the need for health safety is the Constitution of the Republic of Poland. Art. 5 specifies the obligation of the state to ensure safety, which is expressed in counteracting any and all, especially unlawful threats and attacks, aimed at the functioning of citizens, under the law and with their goodwill, in a spirit of trust in state authorities. Ensuring safety requires a narrow interpretation, as it should only be a certain reaction, also of a preventive nature, to actual or potential (but real) threats and attacks (Sarnecki in: ed. Garlicki, ed. Zubik, 2016). In turn, Art. 68 sec. 1 of the Constitution of the Republic of Poland provides everyone, regardless of citizenship or the fact of having insurance, with the right to have access to health care. In accordance with Art. $68 \mathrm{sec} .4$ of the Constitution of the Republic of Poland, combating epidemic diseases and preventing negative health effects of environmental degradation is the duty of public authorities (Constitution of the Republic of Poland of 2 April 1997 (Journal of Laws of 1997, No. 78, item 483, as amended), Chapter 1, Art. 5, and Chapter 2, Art. 68, sec. 1 and 4).

Detailed regulations in this respect are contained primarily in the Act of 5 December 2008 on preventing and combating infections and infectious diseases in humans (Journal of Laws of 2020, item 1845, as amended), as well as the Sanitary Inspection Act, which is the subject of further analysis, focused on sanitary-epidemiological safety.

\section{Amendments to the Act on the State Sanitary Inspection - new instruments of the State Sanitary Inspection}

8 March 2020 saw the entry into force of the Act on special solutions related to the prevention, counteracting and combating of COVID-19, other infectious diseases and crisis situations caused by them (Act of 2 March 2020 on special solutions related to the prevention, counteracting and combating of COVID-19, other infectious diseases and crisis situations caused by them (Journal of Laws of 2020, item 374, as amended)), which was the result of some of the first legislative actions to address the growing threat of the spread of SARS CoV-2 infections and the first to address amendments to the Sanitary Inspection Act, in addition to amendments to other acts, including the Act on preventing and combating infections and infectious diseases in humans. The explanatory memorandum to the Act points out the necessity of introducing specific solutions allowing to take actions minimizing the threat to public health, complementing the principal regulations. On the other hand, the Regulatory Impact Assessment (RIA) accompanying the Act specifies that it is aimed at preparing the state administration for the possible necessity of facing an epidemic of the new infectious disease: COVID-19. At the same time, attention was 
drawn to the need to prepare for the scenario in which Poland will have to take special actions to ensure the safety of its citizens threatened by this virus (Draft Act on special solutions related to the prevention, counteracting and combating of COVID-19, other infectious diseases and crisis situations caused by them with a justification. Print No. 265 of 1 March 2020).

The introduction of changes to the Sanitary Inspection Act should raise no questions. The Act, regulating the authority of the State Sanitary Inspection as established to carry out public health tasks in order to protect human health from the adverse impact of harmful and onerous environmental factors, prevent the outbreak of diseases, including infectious and occupational diseases, where the performance of the above tasks consists of preventive and ongoing sanitary supervision, preventive and anti-epidemic activities with regard to infectious diseases and other diseases caused by environmental conditions, as well as educational and health activities (Act of 14 March 1985 on the State Sanitary Inspection (Journal of Laws of 2021, item 195), Chapter 1, Art. 1 and 2), is a specific legal document for ensuring sanitary-epidemiological safety.

At this point, it is important to note the new powers (instruments/legal measures) given to the State Sanitary Inspection in connection with the emerging information about the new coronavirus. These instruments are expressed in previously unforeseen forms and modes of action, and in view of the case law, result from the introduced legal norms of a nature strictly related to competencies (Ruling of the Voivodeship Administrative Court in Kraków of 3 March 2009, file ref. no. II SA/ $\mathrm{Kr}$ 64/09). Undoubtedly, the sanitary-epidemiological service must be particularly focused on the diagnosis, prevention and control of infectious diseases (Janik, 2012, p. 115), and the Chief Sanitary Inspector should have appropriate and effective statutory instruments available in order to respond immediately when the key goods protected by law, i.e., life and health of citizens, are threatened (Ruling of the Supreme Administrative Court of 17 January 2018, file ref. no. II OSK 811/16).

Particularly noteworthy is the amendment of the Sanitary Inspection Act by way of addition of Art. 8a sec. 5-8. The amendments entered into force on 8 March 2020. The new provisions were introduced by Art. 17 of the aforementioned Act of 2 March 2020 on special solutions related to the prevention, counteracting and combating of COVID-19, other infectious diseases and crisis situations caused by them. These regulations were subsequently amended (Act of 31 March 2020 on amending certain acts with regards to the health care system related to the prevention, counteracting and combating of COVID-19 (Journal of Laws of 2020, item 567, as amended), Art. 1.1 let. $a$ and $b$ ) primarily by expanding the catalog of entities that may, under the authority of the Chief Sanitary Inspector, use the measures listed therein.

In its present form, Art. 8a sec. 5 of the Sanitary Inspection Act allows the Chief Sanitary Inspector or another State Sanitary Inspector authorized by the Chief Sanitary Inspector to issue a decision against the entities indicated in the Act 
(including legal persons, natural persons and organizational units not having legal personality, in particular health care entities, employers) which imposes an obligation to undertake certain preventive or control measures, and to demand information in this scope or distribution of, i.a., personal protective equipment from producers, distributors or importers, as well as recommendations and guidelines defining the course of action in the course of carrying out tasks - in case of an epidemic threat or in case of a danger of spreading an epidemic or an infectious disease which may pose a threat to public health, in particular in the case of an outbreak of a particularly dangerous or highly contagious disease, referred to in the regulations on preventing and combating infections and infectious diseases in humans. Legal instruments will therefore be decisions, recommendations and guidelines, which can be applied (issued) to the above-mentioned group under the conditions indicated therein.

It is worth noting that a multitude of circumstances is indicated, with varying degrees of impact on sanitary-epidemiological safety, each of which individually may result in the issuance of the indicated acts. This includes the state of epidemics, the state of epidemic emergency, while the epidemic is defined as the occurrence in a given area of infections or infectious diseases with a number of infections significantly greater than in the previous period, or the occurrence of infections or infectious diseases not previously occurring (Act of 5 December 2008 on preventing and combating infections and infectious diseases in humans (Journal of Laws of 2020, item 1845, as amended), Chapter 1, Art. 2, sec. 9), as well as the danger of spreading an infection or infectious disease that may pose a threat to public health.

As can be seen from the above, the provision does not contain a gradation based, e.g., on the scale of phenomena when issuing decisions, recommendations or guidelines. It is only necessary for one of the circumstances to exist in order for the prerequisite for the issuance of the acts indicated to be fulfilled. In the case of the dynamics of the spread of the SARS-CoV-2, the outbreaks of infection and the associated response rate, where, in addition, the provision itself does not specify what exactly preventive or control activities may be subject to the obligation - in the case it is imposed by a decision - is a reasonable solution in this regard, inherent in the effectiveness of the goal of ensuring sanitary-epidemiological safety.

When analyzing the Art. $8 \mathrm{a}$ sec. 5 item 2 of the Sanitary Inspection Act, it should also be emphasized that with respect to the recommendations and guidelines indicated therein, reference is made to the possibility of issuing them. The phrase "may issue" in the provision gives rise to the conclusion that the Chief Sanitary Inspector, or any other State Sanitary Inspection body under the authority of the Chief Sanitary Inspector, is not required to issue them. At the same time, the said provision of the Act does not regulate their issuance upon request, which would prove that it is within the authority's discretion to take the initiative in this regard.

It is necessary to address separately the fact that the provision also includes within its scope the issuance of (administrative) decisions imposing the obligations 
listed therein (Art. 8a sec. 5 item 1 of the Sanitary Inspection Act), therefore the above may apply to them accordingly. At this point, however, some comments should be made on the application of the Code of Administrative Procedure (Act of 14 June 1960 - Code of Administrative Procedure (Journal of Laws of 2021, item 735)) (Code of Administrative Procedure, Code).

First, it must be noted that ever since the entry into force of the Sanitary Inspection Act, Art. $37 \mathrm{sec}$. 1, which provides that in proceedings before the State Sanitary Inspection bodies, the provisions of the Code of Administrative Procedure shall apply, and therefore it applies to decisions as well. Therefore, it is difficult to justify the introduction by the discussed amendment of Art. 8a sec. 6, in the part concerning the phrase, in the light of which the provisions of the Code of Administrative Procedure apply to the decisions referred to in sec. 5 item 1 (decisions imposing obligations).

The possible justification of applying the Code of Administrative Procedure to the decisions themselves, as well as to the stage after their issuance with the indicated differences, does not find support in the case law developed so far. It should be pointed out that the judicature recognizes that the phrase "to the decision" means "to the issuance of the decision", and thus the order to apply all provisions remaining in connection with the issuance of the decision, i.e., the provisions governing the procedure that ends with the issuance and delivery of the decision, and the provisions that regulate further proceedings in the case ending with the issuance of the decision (i.a., Ruling of the Supreme Administrative Court of 18 October 2013, file ref. no. I OSK 1632/13; Ruling of the Voivodeship Administrative Court in Warsaw of 4 December 2019, file ref. no. II SA/Wa 1169/19). Considering the above, it should be assumed that the additional indication in the provision to apply the provisions of the Code, is a superfluum (surplus, inflation of the law). It would be sufficient to point to the listing differences in regulations between the aforementioned Art. 8a sec. 6 of the Sanitary Inspection Act and the Code of Administrative Procedure.

It is worth noting at this point the issue of the initiation of administrative procedures. In fact, the position that "Where a substantive law provision does not expressis verbis normalize the initiation of the procedure in a given category of administrative matters, it should be assumed that if the subject matter of the administrative proceedings is the determination of obligations incumbent on an individual, limitation or withdrawal of rights - the initiation of proceedings occurs ex officio" can be found in the literature (Adamiak in: Adamiak, Borkowski, 2014, p. 309). In principle, therefore, it may be assumed that, as regards the adoption of decisions imposing obligations, the procedure should be initiated ex officio, bearing in mind the comments made above on the recommendations and guidelines with the addition that the provision only covers the power to issue a decision imposing the said obligation, which could mean that a decision to refuse to impose an obligation cannot be issued and, therefore, that the request procedure cannot be used. 
A broader analysis of the initiation stage of the procedure for issuing the decision in question goes beyond the scope of this article, therefore it shall be limited to the above-mentioned considerations.

When discussing the issue of the decisions in question, the Sanitary Inspection Act sets out different regulations concerning them. Therefore, the mentioned Art. 8a sec. 6 of the Sanitary Inspection Act is significant both for the party to the decision and the authority issuing it. It stipulates that the decisions referred to in sec. 5 item 1 are subject to the provisions of the Act of 14 June 1960 - Code of Administrative Procedure (Journal of Laws of 2020, items 256, 695, 1298 and 2320, and of 2021, item. 54), with the proviso that they shall be immediately enforceable upon delivery, oral issuance or announcement (item 1); they shall not require justification (item 2 ); they may, in urgent cases, be issued orally and then immediately confirmed in writing (item 3); an appeal shall be lodged within 2 working days from the date of delivery, announcement or confirmation in writing of a decision issued orally (item 4); an appeal lodged shall be forwarded to the appellate authority within 1 working day and shall be processed within 5 working days from the date of delivery of the appeal (item 5).

The above is undoubtedly intended to speed up the administrative procedure for imposing obligations by way of a decision. It is worth pointing to the possibility of immediate execution of the decision effective the moment it is issued (a contrario: when delivery or announcement of the decision has not taken place), the lack of a requirement for justification or the reduction of the time limit for filing an appeal from 14 days (as provided for in Art. $129 \$ 2$ of the Code of Administrative Procedure) to 2 working days and the reduction of the time limit for processing an appeal from 1 month (as provided for in Art. $35 \$ 3$ of the Code of Administrative Procedure) to 5 working days.

A decision is therefore an administrative decision (administrative act), which is a binding, unilateral decision of an administrative authority, based on the applicable legal provisions (Romanska in: ed. Knysiak-Sudyka, 2019).

As per the Announcement of the President of the Personal Data Protection Office (PUODO) of 5 May 2020 (Announcement of the President of the Personal Data Protection Office https://uodo.gov.pl/pl/138/1516; accessed 6 May 2021), relating to the grounds for processing personal data, an example of such a decision may be, for example, the decision to take temperature measurements.

In turn, an example of the application of one of the legal measures provided for in the discussed provision of Art. 8a sec. 5 of the Sanitary Inspection Act is undoubtedly the Anti-epidemic guidelines of the Chief Sanitary Inspector of 19 November 2020 (Anti-epidemic guidelines of the Chief Sanitary Inspector of 19 November 2020 for kindergartens, preschool units and other forms of preschool education and childcare institutions for children up to the age of 3, issued pursuant to Art. 8a sec. 5 item 2 of the Act of 14 March 1985 on the State Sanitary Inspection (Journal of 
Laws of 2019 item 59, and 2020 items 322, 374, 567 and 1337) https://www.gov.pl/ web/gis/wytyczne-przeciwepidemiczne--koronawirus-sars-cov-2).

It is worthwhile to determine the nature of the legal instruments in view of the aforementioned guidelines, since they are a kind of novelty among the issued acts, which also raises doubts as to their meaning. This is not only because of the relatively recent introduction of the legislation on which they are based, but also the content of the legislation itself. In assessing them, therefore, it must be concluded that the guidelines unquestionably do not fit into any source of law listed in the Constitution of the Republic of Poland. The linguistic interpretation of the provision invoked requires reference to the rules of the Polish language, which has given a strict meaning to the word "wytyczne/a", "guideline(s)" in English. The PWN Polish language dictionary defines the word "wytyczna" (trans. guideline) as "wskazówka określająca sposób działania", i.e., an instruction specifying a course of action (Słownik języka polskiego PWN https://sjp.pwn.pl/szukaj/wytyczne.html). Whereas the word "wskazówka", or its English translation - "instruction" in this context means pouczenie dotyczące postępowania", i.e., directions for action, or "informacja o czyms', i.e., information about something (Słownik języka polskiego PWN https:// sjp.pwn.pl/szukaj/wskazówka.html). However, it is necessary to mention the content of Art. 8a sec 8 of the Sanitary Inspection Act, according to which "Persons staying or residing on the territory of the Republic of Poland are obliged to comply with the recommendations and guidelines of the bodies of the State Sanitary Inspection, referred to in sec. 5 item 2". Consequently, taking into account the meaning of the term "guidelines", which does not have the nature of a source of law, it seems possible to understand them as having an informative, instructive character in the sense that the guidelines are binding upon everyone staying or residing in the territory of the Republic of Poland. The obligation arising from the wording of the above provision could be understood to mean that each person is obliged to keep the guidelines in mind when performing their tasks. These guidelines and, similarly, recommendations can be considered in this sense in terms of good practice. The fact that the analyzed regulations do not provide a clear answer as to whether the guidelines are binding is also mentioned when analyzing other guidelines of the Chief Sanitary Inspector (Bursztynowicz, 2020).

In making a determination of the nature of the guidelines, it is also helpful to refer to the division into hard law and soft law. In the literature, attention is currently drawn to the changing nature of legislation - the phenomenon of decreasing the importance of stable, general and precise legislation, and increasing the importance of the law, which is a reaction to specific (usually here and now) socio-economic conditions. Consequently, hard law administrative regulations are increasingly supplemented by soft law. Soft law instruments push the law beyond its traditional 
boundaries. The instruments are official standards, good practice codes, the right to good administration - most standards function (because they are not binding) based on the authority of the party issuing it (Kokocińska, 2020, p. 155). Bearing in mind the division thus presented, guidelines as not being a traditional source of law and not falling into the category of hard law, which may be viewed in the informational, instructive dimension as a reaction to specific conditions (the case for their issuance specified in the regulation - a state of epidemic emergency, a state of epidemic or in the event of danger of the spread of an infection or an infectious disease, which may pose a threat to public health) constitute a form similar to soft law. It may be seen as supplementary to the ordinances of the Council of Ministers on establishing certain restrictions, orders and prohibitions due to a state of epidemic, issued on the basis of Art. 46a and Art. 46b items 1-6 and 8-13 of the Act of 5 December 2008 on preventing and combating infections and infectious diseases in humans. Issuing guidelines strictly addressed to individual recipients also gives the possibility to define the standards of conduct in more detail, as exemplified by the content of the above-mentioned Guidelines.

The application of the instruments set out in the provision of Art. $8 \mathrm{a}$ sec. 5 of the Sanitary Inspection Act may also in certain cases affect aspects of personal data protection. In response to the above issue, as evidenced by the announcement of 27 March 2020 and the attached letter from President of the Personal Data Protection Office (PUODO) dated March 2020, ref. no.: DOL.023.347.2020 (Announcement from the President of the Personal Data Protection Office https://uodo.gov.pl/ $\mathrm{pl} / 138 / 1471$ ), any decisions, guidelines, and recommendations the Chief Sanitary Inspectorate issues to various entities under this provision will provide a legal basis for the processing of personal data by them. To be more precise, the legal measures taken by the Chief Sanitary Inspector or the authorized bodies of the State Sanitary Inspection, regarding preventive, control and other actions in the case specified therein, constitute a premise for the processing of personal data governed by the Regulation (EU) 2016/679 of the European Parliament and of the Council of 27 April 2016 on the protection of natural persons with regard to the processing of personal data and on the free movement of such data, and repealing Directive 95/46/EC (General Data Protection Regulation) (OJ EU L 119, 4 May 2016, p. 1, as amended). It should be noted, however, that in the letter the President of the Personal Data Protection Office stipulates that the actions taken should be tailored in such a way that - acting in accordance with the law - they do not violate the essence of autonomy of the individual, while at the same time fulfilling public health tasks. This is therefore not a matter without the need for a case-by-case analysis and assessment, bearing in mind the aforementioned independence and the performance of tasks that are part of public health in the course of the activities undertaken. 


\section{Summary}

Analyzing the amendments to the Sanitary Inspection Act, it should be considered that the direction of the statutory changes had in mind the situation that arose and ensuring safety, including sanitary-epidemiological safety, against SARS-CoV-2 infections and the COVID-19 infectious disease. This is evidenced by the foreseen possibility of using new instruments in specific cases related to infections or infectious diseases, rapid rate of issuing and executing decisions imposing obligations specified by the Act on the State Sanitary Inspection, the possibility of specific supplementation of the existing regulations by issuing recommendations and guidelines in relation to particular recipients, which gives possibility of detailed definition of norms of conduct. It will also be possible to use the new measures provided for in the Sanitary Inspection Act in the future, particularly in the case of possible epidemics caused by unknown, new diseases. The difference between instruments, where the decision is a sovereign form of action of an authority and whose regulations are more precise, and guidelines and recommendations, which in turn seem to be tools devoid of sovereignty, was also highlighted. Given the relatively short period of time since the introduction of the regulation, lack of developed case law, comprehensive literature on the instruments in question, the article was limited to the presented analysis, which is also the starting point for further examination of the issue.

\section{BIBLIOGRAPHY}

[1] Act of 31 March 2020 on amending certain acts with regards to the health care system related to the prevention, counteracting and combating of COVID-19 (Journal of Laws of 2020, item 567 , as amended).

[2] Act of 23 January 2020 amending the Act on the State Sanitary Inspection and certain other acts (Journal of Laws of 2020, item 322).

[3] Act of 2 March 2020 on special solutions related to the prevention, counteracting and combating of COVID-19, other infectious diseases and crisis situations caused by them (Journal of Laws of 2020 , item 374 , as amended).

[4] Act of 23 January 2009 amending certain acts in connection with changes in the organization and division of public administration tasks within a voivodeship (Journal of Laws of 2009 No. 92 item 753, as amended).

[5] Act of 5 December 2008 on preventing and combating infections and infectious diseases in humans (Journal of Laws of 2020, item 1845, as amended).

[6] Act of 24 August 2001 amending the Sanitary Inspection Act and certain acts (Journal of Laws of 2001, No. 128, item 1407, as amended).

[7] Act of 16 February 2001 amending the Sanitary Inspection Act, the Act on the establishment of the Agricultural Market Agency, the Act on the establishment of the Agency for Restructuring and Modernization of Agriculture, the Act - Customs Code, the Act on control of infectious animal diseases, examination of animals for meat and the Veterinary Inspection, and the Act on the administration of foreign trade in goods and services (Journal of Laws of 2001, No. 29, item 320). 
[8] Act of 24 July 1999 amending the Act on departments of state administration and certain other acts (Journal of Laws of 1999 No. 70, item 778).

[9] Act of 24 July 1998 on the amendment of certain acts determining the competencies of public administration authorities - in connection with the reform of the state system (Journal of Laws of 1998, No. 106, item 668, as amended).

[10] Act of 14 March 1985 on the State Sanitary Inspection (Journal of Laws of 2021, item 195).

[11] Act of 14 June 1960 - Code of Administrative Procedure (Journal of Laws of 2021, item 735).

[12] Act of 25 July 1919 on combating infectious diseases and other common diseases (Journal of Laws of 1919 No. 67, item 402).

[13] Adamiak, B., [in:] Adamiak, B., Borkowski, J., 2014. Kodeks postępowania administracyjnego. Komentarz, ed. 13, Warsaw: Publishers C.H. Beck.

[14] Announcement of the President of the Personal Data Protection Office of 27 March 2020 https:// uodo.gov.pl/pl/138/1471 [accessed: 25 April 2021].

[15] Announcement of the President of the Personal Data Protection Office of 5 May 2020 https:// uodo.gov.pl/pl/138/1516 [accessed: 4 May 2021].

[16] Anti-epidemic guidelines of the Chief Sanitary Inspector of 19 November 2020 for kindergartens, preschool units and other forms of preschool education and childcare institutions for children up to the age of 3, issued pursuant to Art. 8a sec. 5 item 2 of the Act of 14 March 1985 on the State Sanitary Inspection (Journal of Laws of 2019 item 59, and 2020 items 322, 374, 567 and 1337) https://www.gov.pl/web/gis/wytyczne-przeciwepidemiczne--koronawirus-sars-cov-2 [accessed: 24 April 2021].

[17] Borucka, A., Łagowska, E., 2020. The role of Polish Armed Forces in the fight against epidemiological threats (SARS-Cov-2). European Research Studies Journal, European Research Studies Journal, Volume XXIII, Special Issue 3, 33-46.

[18] Bursztynowicz, M., 2020. Konsekwencje niezastosowania się do wytycznych śmieciowych GIS przez przedsiębiorców, LEX/el.2020 [accessed: 28 April 2021].

[19] Cianciara, D., 2011. Zdrowie publiczne w Polsce przed II wojną światową - lekcja dla współczesnych. Przeglad Epidemiologiczny, Vol. 65, No. 4, 635-641.

[20] Constitution of the Republic of Poland of 2 April 1997 (Journal of Laws of 1997, No. 78, item 483, as amended).

[21] Czechowicz, S., 2020b. Pojęcie bezpieczeństwa sanitarno-epidemiologicznego i jego konteksty prawne, Opolskie Studia Administracyjno-Prawne, 18(3), 9-24; DOI: https://doi.org/10.25167/ osap.2586 [accessed: 4 May 2021].

[22] Czechowicz, S., 2020a. Wpływ krajowych regulacji prawnych na kształtowanie się poziomu bezpieczeństwa sanitarno-epidemiologicznego w Polsce, Konteksty Społeczne, Vol. 8, No. 1 (15), 70-91; DOI: http://doi.org/10.17951/ks.2020.8.1.70-91 [accessed: 4 May 2021].

[23] Decree of 11 April 1945 on the division of the Ministry of Labor, Welfare and Health, established by the Act of 31 December 1944 (Journal of Laws of 1945 No. 12, item 63).

[24] Decree of 14 August 1954 on the State Sanitary Inspection (Journal of Laws of 1954 No. 37, item 160).

[25] Draft Act on special solutions related to the prevention, counteracting and combating of COVID-19, other infectious diseases and crisis situations caused by them with a justification. Print No. 265 of 1 March 2020; https://www.sejm.gov.pl/Sejm9.nsf/PrzebiegProc.xsp?nr=265 [accessed: 24 April 2021].

[26] Janik, M., 2012. Policja Sanitarna. Warszawa: LEX a Wolters Kluwer business. 
[27] Kaczocha, M., 2017. Ustawa o Państwowej Inspekcji Sanitarnej. Komentarz, LEX/el., commentary on Art. 3 [accessed: 4 May 2021].

[28] Klingberg, A. M., 1946. Stan epidemiczny Polski w 1945 r., 11-45, [in:] Morzycki, J., Klingberg, A. M., 1946. Naczelny Nadzwyczajny Komisariat do Walki z Epidemiami w latach 1944-1945. Warszawa: Lekarski Instytut Naukowo-Wydawniczy. Dostępne pod adresem: https://zbc.ksiaznica. szczecin.pl/dlibra/publication/570/edition/491/content?ref=desc [accessed: 4 May 2021].

[29] Kokocińska, K., 2020. Państwo Administracji, Acta Universitatis Wratislaviensis No 4001 PRAWO CCCXXXI, Wrocław, 155; DOI: https://doi.org/10.19195/0524-4544.331.13 [accessed: 4 May 2021].

[30] Morzycki, J., 1947. Sprawozdanie z działalności Nadzwyczajnego Komisariatu do Walki z Epidemiami za lata 1944-1945, 8, [in:] Przeglad Epidemiologiczny. Kwartalnik. Rok 1. Nr 1, Wydawnictwo: Naczelny Nadzwyczajny Komisariat do walki z epidemiami i Lekarski Instytut Naukowo-Wydawniczy. Dostępne pod adresem https://epibaza.pzh.gov.pl/sites/default/files/ Przegl\%C4\%85d\%20Epidemiologiczny\%201947\%20nr\%201.pdf [accessed: 4 May 2021].

[31] Ordinance of the Minister of Health of 13 March 2020 on declaring the state of epidemic hazard in the territory of the Republic of Poland (Journal of Laws of 2020, item 433, as amended).

[32] Posobkiewicz, M., Kalinowska-Morka, J., Świekatowski, B., 2015. Państwowa Inspekcja Sanitarna - 60 lat istnienia i 95 lecie funkcjonowania Służb Sanitarnych w Polsce, Przegląd Epidemiologiczny, Vol. 69, No. 1, 113-119.

[33] Principal Sanitary Act of 19 July 1919 (Journal of Laws of 1919 No. 63, item 371).

[34] Principal Sanitary Act of February 1919 (Journal of Laws of 1919, No. 15, item 207).

[35] Regulation (EU) 2016/679 of the European Parliament and of the Council of 27 April 2016 on the protection of natural persons with regard to the processing of personal data and on the free movement of such data, and repealing Directive 95/46/EC (General Data Protection Regulation) (OJ EU L 119, 4 May 2016, 1, as amended).

[36] Regulation of the Minister of Health of 13 March 2020 on the declaration of a state of epidemic emergency on the territory of the Republic of Poland (Journal Laws of 2020, item 433, as amended).

[37] Regulation of the Minister of Health of 20 March 2020 on the declaration of a state of epidemic emergency on the territory of the Republic of Poland (Journal of Laws of 2020, item 491, as amended).

[38] Regulation of the Minister of Health of 20 March 2020 on the declaration of a state of epidemic emergency on the territory of the Republic of Poland (Journal of Laws of 2020, item 491, as amended).

[39] Romańska, M., [in:] ed. Knysiak-Sudyka, H., 2019. Kodeks postępowania administracyjnego. Komentarz. 2nd ed. Warsaw: Wolters Kluwer Polska. LEX/el, commentary on Art. 104 [accessed: 4 May 2021].

[40] Ruling of the Supreme Administrative Court of 17 January 2013, file ref. no. II OSK 811/16, LEX no. 2464406.

[41] Ruling of the Supreme Administrative Court of 18 October 2013, file ref. no. I OSK 1632/13, LEX no. 1612043.

[42] Ruling of the Voivodeship Administrative Court in Kraków of 3 March 2009, file ref. no. II SA/ Kr 64/09, LEX no. 533314.

[43] Ruling of the Voivodeship Administrative Court in Warsaw of 4 December 2019, file ref. no. II SA/Wa 1169/19, LEX no. 3041443. 
[44] Sarnecki, P., [in:] ed. Garlicki, L., ed. Zubik, M., 2016. Konstytucja Rzeczypospolitej Polskiej. Komentarz. Vol. I, Sejm Publishing House, 2nd ed., Warsaw, LEX/el, commentary on Art. 5 [accessed: 4 May 2021].

[45] Serwis Rzeczypospolitej Polskiej - the official website of the Polish government https://www. gov.pl/web/zdrowie/pierwszy-przypadek-koronawirusa-w-polsce [accessed: 4 March 2020].

[46] Seweryn, M., 2015. Funkcjonowanie Państwowej Inspekcji Sanitarnej. Historia, rozwój, wyzwania. Zdrowie Publiczne i Zarządzanie; Vol. 13, No. 2, 158.

[47] Słownik języka polskiego PWN (trans. Polish language dictionary) https://sjp.pwn.pl/szukaj/ wytyczne.html [accessed: 4 May 2021].

[48] Słownik języka polskiego, PWN. (trans. Polish language dictionary) https://sjp.pwn.pl/szukaj/ wskaz\%C3\%B3wka.html [accessed: 4 May 2021].

[49] Stan sanitarny kraju w roku 2018, 2019. Raport Głównego Inspektoratu Sanitarnego, Warszawa, 15. Dostępne pod adresem: https://gis.gov.pl/wp-content/uploads/2019/09/SSK-2018-www-1. pdf [accessed: 25 April 2021]. 
